\title{
A poética do cotidiano missioneiro: etnografia e reflexão sobre si mesmo. Compartilhando imagens e emoções com os contadores de causos nas Missões Gaúchas
}

\author{
Flávio Leonel Abreu da Silveira
}

\begin{abstract}
resumo $A$ intenção deste trabalho é situar o leitor no panorama etnográfico no qual ocorreu a pesquisa de campo, tentando apresentar algumas questôes relevantes para o exercício etnográfico percebido como um encontro intersubjetivo. Nestes termos, as emoçôes envolvidas na poética do cotidiano missioneiro arrebatam o etnógrafo, ao mesmo tempo em que apontam para a desconstrução de certas visóes de mundo, implicando num redimensionamento teórico e intelectual, a partir da uma experiência dialógica intersubjetiva dada no convívio com o Outro.
\end{abstract}

palavras-chave Emoçóes. Etnografia. Informante.

\section{Breve panorama da pesquisa de campo}

A pesquisa de campo realizada por mim entre os anos de 2001 e 2002 na regiáo noroeste do Estado do Rio Grande do Sul, comumente denominada de Região Missioneira, esteve pautada na tentativa de compreender os vínculos simbólico-afetivos das populaçôes missioneiras com as suas paisagens de pertencimento. Nestes termos, realizei um intenso diálogo com os "contadores de causos" sobre alguns temas capazes de revelar a simbólica presente nas interações dos grupos humanos com o meio. Entre eles estão as narrativas de "assombros" e "visages" envolvendo formas monstruosas e fantasmáticas que habitam as paisagens missioneiras, acerca dos ciclos revolucionários que apontam as violências vividas durante as guer- ras campeiras na região associadas à presença de espíritos que assombram os vivos, bem como às narrativas relacionadas à labuta junto às roças - considerando os "puxirôes" que ocorriam no passado sempre seguidos de festejos e bailes - e ao trato do gado.

\section{Questóes em torno do estatuto do informante em etnografia}

Há reflexóes estimulantes quanto ao papel desempenhado pelo "informante" no exercício etnográfico, como as experiências apontadas nos trabalhos clássicos de William Foote-Whyte (1980) no espaço urbano de Cornerville onde Doc aparece como uma figura de extrema importância para aquele antropólogo em sua vivência no bairro, ou de Gerald Berreman (1980) na sua estada no Himalaia, quando as presenças alternadas dos intérpretes-informantes, Sharma e Mohammed, colocaram o problema da inserção do antropólogo em campo, assim como a questâo evidente de que o informante é ao mesmo tempo um interpretante de sua cultura.

As consideraçóes de Maurizio Catani (1983) em sua análise sobre a história de vida de Tante Suzanne em Paris, demonstraram o nível poético da experiência dessa senhora como narradora. Um conjunto de canções e a presença do jardim de sua casa auxiliaram no reordenamento do tempo, estimulando o exercício fabulatório da memória dessa idosa. A importância da ambiência emocional engendrada pela senhora 
implicou no envolvimento afetivo do pesquisador com sua informante.

A experiência de Evans-Pritchard (1993) junto aos nuer é outra referência emblemática para as reflexóes em torno das situaçóes envolvendo o antropólogo em campo que, ao interagir com os informantes, experimenta as tensóes da relação com estes, como evidência das complexidades presentes na relação com o Outro.

Talvez tenha sido a publicação do diário de campo de Bronislaw Malinowski (1997) e suas consideraçóes explícitas acerca das vicissitudes da relação com os nativos, que acabou por trazer novos elementos para a reflexão sobre o papel do chamado informante na vivência do antropólogo em campo, deixando vir à tona as impressóes não reveladas do pesquisador em relaçáo a ele.

O "diário" evidencia que atrás desta categoria de pensamento cara ao métier antropológico, existem sujeitos situados em sua cultura de forma dinâmica, realizando escolhas e emitindo conclusões que também dizem respeito à presença desse sujeito estranho que adentra o seu espaço de interação social. Assim, o informante é um interpretante tanto de sua cultura como daquela que o antropólogo carrega consigo, da qual jamais pode se desprender. Enquanto isso, o antropólogo revela-se como sujeito situado e idiossincrático, com filtros culturais e uma biografia que nele pulsam na medida em que interage com o nativo.

Aquele que surgiu na matriz disciplinar em antropologia (Cardoso de Oliveira, 1986), enquanto um paradigma de desordem - sendo denominado de "antropologia pós-moderna"1

1. "Do seu ponto de vista tende a problematizar as condições do trabalho etnográfico, querendo representar de modo convincente as particularidades dos seus objetos de estudo. Perturbando o equilíbrio 'natural' entre subjetividade e objetividade, deseja mostrar o sentido do trabalho de campo, dos microprocessos da vida cotidiana, da assimetria política e econômica do encontro etnográfico, da tradução através dos confins lingüísticos e culturais” (Malighetti, 1996, p. 79).
- não se furtou de considerar tal problemática no ofício do etnógrafo. O exemplo de Paul Rabinow (1988) que durante a sua pesquisa no Marrocos experienciou uma relaçấo com Ben Mohammed, personagem que se negava a assumir a posição de "informante", permitiu a sua reflexão sobre noção aristotélica de "amizade", apontando um diferencial entre Ben Mohammed - "o amigo" - e as demais pessoas com as quais interagiu, vistas enquanto informantes. A experiência de Paul Rabinow é interessante para a reflexão a que me proponho. Portanto, a retomarei mais adiante quando tratar sobre a minha experiência de campo.

As reflexões do meta-etnógrafo James Clifford (1998) referentes à invasão da "heteroglossia” na narrativa etnográfica, enquanto um texto que se propóe a realizar interpretaçóes acerca das culturas, também aponta para a problemática existente no uso da categoria informante na produção antropológica. $\mathrm{Ou}$ seja, considera suas implicações epistemológicas dentro do corpo da disciplina. $\mathrm{O}$ autor argumenta que a utópica intenção presente nos "textos múltiplos" de estabelecer voz ao outro como um "colaborador" que "escreve" o texto tanto quanto o etnógrafo, surgindo assim, não apenas enquanto um sujeito de enunciação de determinadas informaçóes, evidencia a questão do estatuto atribuído àquelas "pessoas" que interagiram intensamente com o antropólogo durante a sua pesquisa, de forma que a presença das mesmas esteja impregnada na etnografia. Clifford vaticina que, para elas "o termo informante náo é mais adequado, se é que algum dia foi" (Clifford, 1998, p. 55).

As reflexóes estabelecidas pelos "pós-modernos" em torno do encontro cultural como uma experiência intersubjetiva, apontam para o fato de que o antropólogo, ao interagir com sujeitos oriundos de sistemas culturais diferentes do seu, experimenta o desencadeamento de complexos processos subjetivos na sua 
própria pessoa (Rosaldo, 1991). Também fica evidente que na pesquisa etnográfica ao estabelecer-se uma relação dialógica na qual os sujeitos se aproximam engendrando um mundo compartilhado, mediante a conversação, origina-se uma tentativa de entendimento desses universos culturais diversos que se tocam, tratando-se de um esforço e uma abertura ao Outro frente à experiência humana de comunicação. Aqui, não há nenhuma intenção de minha parte, como lembra Vincent Crapanzano (1991), de substituir a observação participante pelo diálogo.

Vital Pasquarelli Júnior, ao analisar a etnografia de Carlos Castańeda, tenta aproximar a visão dialógica trazida pela "vertente experimental" em etnografia com um "pensamento por imagem", inspirado na perspectiva durandiana das "estruturas antropológicas do imaginário" para escapar da falácia de um dialogismo ingênuo. $\mathrm{O}$ autor considera que o diálogo

aparece possuindo natureza de conhecimento, aprendizado e reflexão que não são identificáveis nos limites da intelecção racionalista, pois realizam e resultam de um movimento - de uma pergunta - para dentro e a partir de uma vivência, ou experiência, acumulada biograficamente (...) O diálogo é essencialmente estar na presença do outro, por isso mesmo é verdadeiramente uma experiência, inscreve-se na integralidade do vivido, não sendo passível de redução ao registro da mera intelecção racional (Pasquarelli Jr., 1995, p. 109-110).

O diálogo não seria método, mas forma para Denis Tedlock (1986). Michael Fischer (1985) argumenta que o diálogo sempre envolve um terceiro (referindo-se às reflexões de Gadamer [1965]) ao se tratar de assuntos da cultura - corrigindo os interlocutores -, quando faz uma crítica a Stephen Tyler para o qual o antropólogo sempre tem o poder porque é ele quem "tem o lápis na mão". Paul Rabinow (1999, p. 97) afirmará que "é fundamental uma atitude dialógica".

A questáo diz respeito, no meu ponto de vista, a uma adesão e compartilhamento de imagens entre os atores em interação. Daí um plano sensível, vivido e matizado pela experiência biográfica dos sujeitos onde as imagens mentais são uma porção complexa e anterior da estrutura cognitiva dos mesmos, dadas nas suas relaçóes com o meio no trajeto antropológico (Durand, 1989) que os une e singulariza. Ao mesmo tempo, que se refere à problemática centrada na "fusão de horizontes" (Gadamer, 1965) quando o diálogo é vivido como experiência singular de abertura ao Outro - uma hermenêutica de reciprocidade -, dada no encontro entre sujeitos situados.

Portanto, é método e forma na própria ação de dialogar, assim como é método e forma na ação de textualizar. Existe método "no fazer antropológico, que é o diálogo entre nossas teorias e as teorias nativas" (Lagrou, 1994) e seria forma, porque existe um formismo no sentido simmeliano, no ato de configurar uma narrativa dialógica e de tecer a tessitura complexa da intriga narrativa (Ricoeur, 1994). Há uma estilização necessária para que os atores sociais em interação, numa co-presença, conformem um estar-junto em relação na própria dinâmica do texto, considerando suas tensóes internas e seu caráter fragmentário na apreensão da riqueza do diálogo. Nestes termos, o diálogo apresenta-se como uma forma de experiência compartilhada, revelando-se excesso de imagens e de sentidos. Quanto à etnografia, seria ela a tentativa parcimoniosa de retê-lo - o diálogo - para que o terceiro - o leitor - possa intervir no texto.

Diante de tais questóes, pretendo tornar claro o rumo que minhas reflexôes seguem a partir deste ponto, pois a intenção não é a de tentar implodir a noçâo de "informante", mas de problematizá-la e explicitar a forma como 
ela aparece na etnografia que realizei, tentando limpar o que me parece um terreno nebuloso em torno desta categoria. Por outro lado, a relaçáo intersubjetiva se explicita como um nível de interação em que os sentimentos colocados no encontro e no diálogo decorrente desse processo, se apresentam como a manifestação de uma via de mão dupla, definindo um desejo comum de adentrar no universo do outro. É necessário, devido a isso, deixar claro que minha experiência é algo muito particular, estando relacionada à inserção como sujeitopesquisador num contexto cultural como é a região missioneira do noroeste do estado do Rio Grande do Sul.

\section{Problematizando a noçáo de informante}

As consideraçóes de Émile Durkheim e Marcel Mauss (1971) em torno das categorias de pensamento são importantes para situarmos aquilo que se compreende como informante no campo acadêmico, mais especificamente, no corpo metodológico e teórico-conceitual da Antropologia. O termo aparece matizado sob um amplo espectro de possibilidades frente às inúmeras formas de inserção dos antropólogos durante a conformação da disciplina, ou ainda, ao longo da história da Antropologia no que tange à legitimação da experiência do trabalho de campo e à observação participante como metodologias imprescindíveis ao ofício do etnógrafo.

As categorias de pensamento atribuem sentido às coisas e à medida que isso ocorre, expressam e manifestam a própria sociedade que opera com as mesmas. Portanto, falam muito do grupo de onde emergem como parte do complexo de imagens e símbolos que este articula em sua experiência no mundo. A cultura é dinâmica em seus processos situados no espaço e na sua sistêmica ao longo da duração, pois perdura no tempo (este aparecendo como uma categoria fundamental) e, por isso, apresentase sempre aberta às mudanças. As categorias, portanto, tendem a variar junto a ela.

O que entendemos por informante se apresenta enquanto uma categoria de pensamento - ou uma representaçáo do Outro (Rabinow, 1999) -, uma ferramenta metodológica que nos auxilia na tarefa de experimentar o estranhamento, "facilitando" o processo de compreensão da cultura do Outro e de "decodificaçáo" de seu intrincado sistema de significados.

$\mathrm{O}$ informante surge como um sujeito oriundo de uma experiência cultural em dada sociedade que é passível de ser analisada em termos acadêmicos. Não há problema nenhum nisso se tomarmos o termo dentro de sua dimensão epistemológica, validando a construção de um conhecimento científico acerca das diversas formas de manifestações daquilo que entendemos como cultura, enquanto um fenômeno complexo e analisável. Além do mais, fica claro que existe uma fronteira definindo estatutos aos sujeitos em interação: limites aparentemente nítidos fazem do jogo entre proximidade e distância uma necessidade na construção do objeto de pesquisa.

Metodologicamente, a categoria informante é internalizada pelo pesquisador que opera com a mesma, de maneira a utilizá-la como um elemento fundamental na construção de sua etnografia. O problema implica nas representações que, por vezes, se têm do Outro e o nível em que se dão as relaçôes pessoais entre os personagens: pesquisador e informantes. $\mathrm{Pa}-$ rece evidente que esse tipo de situação envolve questóes subjetivas no que se refere à abertura à diferença - o antropólogo enquanto um sujeito idiossincrático -, mas também das opçôes teórico-conceituais em que a relação de proximidade-distância é central na experiência etnográfica do estranhamento.

Georg Simmel (1983) já demonstrou que o fenômeno do estrangeiro é uma experiência 
positiva, exatamente por forçar o sujeito que se desloca na busca do contato intercultural a viver esse jogo entre proximidade e distância que atinge também aquele que interage com ele enquanto "receptor". Esse tipo de descentramento frente à alteridade detém algo de contrastivo, sendo de extrema importância para a compreensão da diferença a partir de uma reflexão sobre si mesmo.

A categoria informante, dessa forma, apresenta-se como um dos elementos importantes para as reflexóes acerca dos fenômenos ditos culturais que, por certo, dizem respeito ao tipo de campo teórico que o antropólogo optou para estabelecer suas análises sobre as experiências vividas durante a pesquisa etnográfica. No entanto, uma antropologia que se proponha interpretativa deve considerar os múltiplos vetores de interação, assim como os diferentes planos de comunicação em que os sujeitos se situam no processo do encontro etnográfico. Isso depende de como a informação flui a partir desses vetores da relação e de como os níveis de informação veiculados no encontro intercultural remetem, por um lado, ao conteúdo do que se informa e, por outro, de como isso acontece, pois no final das contas, tudo depende de quem é o Outro para o interpretante ${ }^{2}$.

2. De acordo com Roberto Malighetti "a concepção interpretativa considera a ciência como constituída de modelos teóricos que constroem os próprios objetos. Por um lado, os objetos não são vistos como entes dotados de propriedades independentemente do ponto de vista do sujeito conhecedor. Por outro, o sujeito não é uma instância paradigmática, um ente 'neutro' que funciona como 'espelho da natureza' (Rorty, 1980). Pelo contrário, é um sujeito histórico, ontologicamente fundado na própria forma de vida, no próprio saber e na própria cultura (...) A superação do objetivismo e do subjetivismo é de natureza circular. Segundo os princípios do círculo hermenêutico, sujeitos e objeto não são estranhos, mas se implicam reciprocamente. O sujeito interpreta um objeto que tem significado só enquanto é colhido por alguém. $\mathrm{Na}$ operação do conhecimento - considerada de um
Há ainda, a necessidade de considerar que ambos - etnógrafo e informante - são detentores de hermenêuticas específicas, por isso capazes de leituras acerca da cultura que o antropólogo tenta compreender em contraposição a que traz consigo, ou seja, deve ficar claro que determinadas pessoas - os "informantes" - que auxiliam o pesquisador em sua proposta de conhecer outra cultura são tão importantes na pesquisa etnográfica quanto o pesquisador. O estatuto de pesquisador é burilado sem, no entanto, perder sua importância epistemológica. Isso não inviabiliza o papel do pesquisador, mas tende a deslocá-lo de sua autoridade tácita para re-situá-lo enquanto sujeito produtor de conhecimento dentro das Ciências Humanas.

É por isso que nesse sistema complexo ocorre também a leitura da própria cultura do antropólogo via olhar do Outro à luz de sua experiência, sobre as formas culturais encarnadas na vivência do etnógrafo como sujeito oriundo de um contexto diverso (com comportamentos, técnicas corporais, crenças, vestimentas, expressões idiomáticas etc.) que interage noutro meio. O próprio informante é capaz de realizar uma releitura de determinados aspectos de sua própria cultura, mediante um caráter comparativo dos valores da cultura do outro em relação a sua.

Os chamados informantes, enquanto atores sociais, agem sobre o antropólogo engendrando re-configuraçôes no exercício etnográfico, desencadeando processos reflexivos no pesquisador que são da ordem da subjetividade. O que parece se evidenciar é o fato de que, em níveis de entendimento diferentes, os sujeitos

ponto de vista metodológico - o sujeito entra com todo o seu saber, deixando-se apanhar pelo objeto. Não tem contraposição objetivante, nem estranheza, mas um vínculo de 'afinidade', de 'pertinência', que liga o intérprete ao que interpreta” (Malighetti, 1996, p. 83). 
da interação colocam-se como pesquisadores tentando compreender a complexidade do mundo, a partir das experiências diversas que detém e que vêm à tona no encontro etnográfico.

A noção de informante traz consigo o mérito de nos colocar a relevância dos fluxos de sentidos presentes na sua relação com o interpretante - esse "decodificador" de símbolos -, mas acima de tudo, no caso da Antropologia, revela uma postura metodológica de distanciamento em relação ao Outro por parte do antropólogo em campo, posto que a idéia de fronteira simbólica é fundamental para uma prática científica epistemologicamente viável na construção da etnografia como texto. No entanto, é preciso refletir sobre os limites que a noção de informante nos impõem nesse processo.

A experiência etnográfica implica em formas complexas de interaçóes e níveis de distanciamento variáveis entre os sujeitos. Há sempre um problema colocado pela variabilidade - de proximidade-distância - existente na construção das relaçóes sociais. Portanto, um problema de proxemia (Hall, 1977), a partir das próprias idiossincrasias do etnógrafo como pessoa, bem como as dos informantes em interação com aquele, ou ainda, de uns com os outros no acontecer da etnografia.

Quero destacar que entendo o termo "informante" como uma categoria polissêmica, abarcando muitos sentidos dentro do corpo das etnografias, mas sempre apontando para um tipo de clivagem que, se necessária até certo ponto para legitimar o próprio antropólogo como ator social no exercício da pesquisa, pode implicar na redução do "informante" à situação de um agente passivo ante uma determinada cultura vista como entidade abstrata que o engloba. A noção de "campo de possibilidades" (Velho, 1994) apontada por uma Antropologia Urbana, bem como os poderosos insights de Norbert Elias têm mostrado que, se há um nível de controle social sobre os sujeitos, também existe uma margem de ação e de estratégias (Certeau, 1994) capazes de auxiliálos a lidar com tais questôes de forma a escapar de certas coerçóes.

Os problemas com o uso do termo informante aparecem nesse nível quando - como em algumas etnografias -, acredita-se "ingenuamente" que se é capaz de elucidar certas problemáticas culturais aos informantes, as quais lhes são inerentes porque vividas. Longe de considerar que as culturas são vítimas de um desígnio perverso, sempre de fora, alóctone, torna-se necessário percebê-los - os informantes - como agentes lidando com suas questôes dentro da própria arena social em que os conflitos se encerram.

A categoria informante aparece na etnografia que realizei como um termo secundário, ainda que imprescindível. Não o usei, portanto, como um elemento definidor de papéis específicos, até porque parece existir em alguns momentos uma espécie de mistura entre eles. O termo, quando utilizado por mim não tem esse cunho redutor que pretende ver o sujeito como mero fornecedor de informaçóes ao antropólogo em campo. A visão do informante na etnografia que realizei faz referência à evocaçáo de imagens e à força narrativa de diferentes personagens acerca de sua cultura, reveladas no encontro intercultural com o antropólogo.

Trata-se muito mais de uma categoria internalizada por mim no processo de realização do trabalho de campo. Dessa forma, sempre operei com a categoria informante dentro de uma lógica específica, sem deixar de considerar a experiência com o Outro como uma vivência pessoal permeada pela complexidade das relaçóes humanas, abertas ao encontro cultural, mas também ao incerto nesse jogo de alteridades. 


\section{$\mathrm{O}$ antropólogo em campo: estratégias e imagens}

Durante a pesquisa etnográfica, convivi com um número significativo de pessoas nas Missóes. Apresento rapidamente algumas delas sem, no entanto, deixar de fazer uma ressalva: várias foram as pessoas que me auxiliaram, às quais detenho grande afeto e respeito, ainda que não as apresente neste artigo. Entre as pessoas de enorme importância para a realização da pesquisa devo destacar seu Emílio que é funcionário do IPHAN e que junto com sua família, especialmente sua esposa dona Cleni, auxiliaram-me enormemente na realização do trabalho de campo. Seu Frutuoso, morador de um assentamento no interior de São Miguel das Missóes foi um grande companheiro na minha experiência missioneira, assim como seu Dorcino, senhor aposentado que colaborou intensamente comigo. Mara Moraes, proprietária de terras em São Miguel, mostrou-se uma pessoa de rara sensibilidade em relação ao meu trabalho, tendo sido o seu auxílio valioso durante a minha permanência nas Missóes gaúchas.

No entanto, de todas as pessoas que conheci, a que mais me impressionou foi seu Emílio. Eu havia conversado com ele por telefone antes de ir morar em São Miguel das Missóes, quando ele se dispôs a me ajudar. Ao travar contato com ele no Museu das Missóes, tive uma surpresa. Esperava encontrar um senhor grisalho, ou mesmo, de cabelos brancos, mas a pessoa que conhecia naquele momento em meio a seus colegas de trabalho era um homem que náo tinha sequer cinqüenta anos de idade. Seus cabelos muito negros eram o exato oposto do que imaginava. Além disso, trazia um olhar curioso e de extrema vivacidade que me impressionou, bem como uma desenvoltura para dialogar que o fazia se sobressair em relação aos seus colegas de trabalho. Havia uma sabe- doria naquele senhor que me causou admiração e curiosidade. Naquele dia, me vi junto a um grupo de pessoas que trabalham no Sítio Arqueológico tendo que explicar a que vinha, os motivos que me traziam aquele lugar. Ao falar nas narrativas que me interessavam mencionei o lobisomem como exemplo, mas também, como uma espécie de provocação para ver a reação deles. Ante a minha colocação, seu Emílio argumentou que era "uma representação". Mais surpresas, primeiro porque parecia reagir positivamente a minha tentativa de diálogo; segundo, com a noção de "representação" que ele utilizava com tamanha segurança e que me soou, naquele momento, como algo significando uma impressão, algo como um falseamento da imagem; terceiro, por se colocar como alguém que apresentava a sua opinião sem a timidez evidente dos demais, frente ao pesquisador da cidade grande, que, por sinal, estava tão intimidado quanto eles.

Ficava evidente para mim que ele me dizia, subliminarmente, algo como: sim eu te auxilio, mas o que te proponho é um diálogo em que existem coisas que não dominas e que posso te orientar na tua busca, mas, além disso, tanto a tua experiência como sujeito no mundo me interessa quanto o teu olhar sobre a minha cultura. Ele me propunha o que, a princípio, interpretei como um encontro intersubjetivo, uma troca de experiências culturais. Outra surpresa, ele se propôs, naquele mesmo dia, a me buscar às $18 \mathrm{~h}$ na Pousada das Missóes, onde eu estava hospedado para conversarmos com algumas pessoas que conhecia.

Desde o início, meu amigo se mostrou como um sujeito pleno de si e dono de sua consciência, por isso, sempre se colocou como alguém que defendia suas posiçóes e detinha sua própria interpretação acerca de sua cultura. Estava frente a uma pessoa, que parecia possuir valores muito claros e visão crítica suficiente para tirar as suas conclusôes acerca de uma série de questóes 
inerentes ao contexto cultural a que pertencia, e que eu ansiava conhecer.

O pensamento de seu Emílio, quando o conheci, pareceu-me complexo demais. Não conseguia compreender o que queria dizer, as construçôes frasais eram diferentes, respeitando uma lógica que eu desconhecia, repleta de palavras estranhas para mim. Além disso, remetia àquilo que poderia ser chamado de uma "linguagem popular". Da mesma forma, não conseguia compreender direito o que algumas pessoas falavam, tendo demorado alguns dias para acostumar o ouvido e conseguir entrar um pouco em sua lógica.

A partir de minha interação com seu Emílio e sua família, passei a compreender melhor a sua forma de pensar, ao mesmo tempo que solicitava que me esclarecesse o significado de alguns termos que náo dominava. $\mathrm{O}$ mesmo acontecia quando eu usava alguma expressão desconhecida por eles, durante as inúmeras conversas à noite em sua casa, fato que suas filhas nunca deixavam passar em branco.

Também sabia que ele auxiliara alguns profissionais de diferentes áreas em suas pesquisas na região e que exercia um cargo de liderança - naquele período ainda era o mestre-de-obras do Sítio Arqueológico -, daí sua desenvoltura ser resultado também de sua atuação no cenário citadino. Sua grande interação social no contexto miguelino se refere tanto ao seu trabalho junto ao Sítio Arqueológico, quanto a sua participação em diferentes pesquisas realizadas na regiáo. Constataria mais adiante, que sua inserção na comunidade miguelina também está relacionada a sua posiçáo como membro ativo da Congregação Cristã no Brasil (CCB). Havia algo naquela pessoa que a singularizava.

Certa feita, estava em frente à pousada e seu Emílio, que passava em frente com sua camionete, parou para conversar comigo. Estava acompanhado de uma mulher de pele muito clara que me apresentaria como sua esposa, dona Cleni, que mais tarde se revelaria outra pessoa fundamental na minha experiência etnográfica. Naquela mesma semana, começaria a freqüentar sua casa e conheceria três de suas quatro filhas: Daniela, a menor de todas; Deisi e Eliane (cujo apelido é Preta) a mais velha entre as filhas que moram com o casal. Meses depois conheceria Elisiane, a primogênita, que é casada e mora em um assentamento no interior da cidade de Jóia.

A relaçáo com seu Emílio sempre esteve pautada num intenso diálogo acerca das questóes relacionadas ao meu trabalho, por exemplo, mas seguidamente extrapolavam tais temas. Compartilhávamos pontos de vista, discordávamos e refletíamos juntos. Um outro fator de expansão no relacionamento com ele foi a presença constante de sua família. Todavia, minha interação com o universo feminino assumiu um ritmo que resguardava certa autonomia em relaçáo ao homem da casa, pois estava marcada pela forte presença das mulheres na mesma. Meu envolvimento com a família crescia à medida que os meses avançavam.

Também passei a me relacionar com a sua família extensa, ou seja, com seu irmão Arlindo (que tem problemas mentais) e sua mãe, dona Elvira, moradores nas proximidades de sua casa, bem como com outras pessoas que, seguidamente, o visitavam. Os irmãos de dona Cleni, especialmente, Algemiro (que também possui problemas mentais), Valter, Sérgio e Luís (Gordo), faziam parte das minhas relaçóes sociais junto à família Santos.

É preciso considerar que, sendo crentes, uma vasta rede de "irmãos" freqüentava a sua moradia, bem como inúmeras pessoas que, em suas passagens pela cidade, vindas do interior do município visitavam a família. A casa, portanto, constituía-se num ótimo espaço social para a realização da etnografia.

Seu Emílio e sua família me auxiliaram enormemente, pois me apresentaram a um 
grande número de pessoas - certamente, quase uma centena, onde entrevistei pelo menos sessenta delas. Além disso, com sua F 100, conduziam-me a vários distritos do município de São Miguel. Com eles fui até São Luiz Gonzaga, Entre-Ijuís, Santo Antônio das Missóes, São Nicolau e Uruguaiana, além de visitar Paso de Los Libres, na Argentina.

Desde a primeira vez que saí com seu Emílio de automóvel pela cidade, percebi a sua solicitude em cumprimentar a todos pelos quais passávamos, fosse nas ruas ou em frente às casas. Trata-se, sem sombra de dúvidas, de uma pessoa com grande inserção na sua comunidade de pertença. Compreendi que a melhor forma de ser bem aceito por ela seria cumprimentando as pessoas, ou seja, não poderia em hipótese alguma manter o jogo de proximidade-distância que estava acostumado em Porto Alegre, onde nem sempre o cumprimento é uma forma de relação entre a vizinhança.

Isso não significava que devesse sair distribuindo cumprimentos à revelia, mas que precisava considerá-los como prática importante nas formas de sociação presentes naquela comunidade citadina com fortíssimos vínculos com a vivência rural. Experienciar isso me pareceu ao mesmo tempo inusitado e extremamente instigante, pois me colocava como um sujeito não-familiar em interação num contexto novo e totalmente desconhecido. Daí o estatuto de estrangeiro, de estranho que detinha para a comunidade nos primeiros meses, ainda que as pessoas já estivessem acostumadas com a presença de inúmeros pesquisadores que habitam temporariamente o espaço urbano e rural da cidade de São Miguel das Missōes, na porção noroeste do estado.

Exercitar o cumprimento a partir do automóvel juntamente com seu Emílio - considerando a sua extensa rede de relaçóes - e, logo depois com sua família, foi muito importante na minha inserção no espaço social miguelino, possibilitando a realização do trabalho de campo. Tal situação também me lançava numa espécie de liminaridade, pelo fato de que estar próximo da família Santos me concedia, até certo ponto, um estatuto de confiabilidade, onde a possível distância aparecia muito mais como um atributo ligado ao desconhecimento acerca de quem eu era e a que vinha, do que da idoneidade do grupo familiar no contexto social miguelino.

Tanto é verdade que passei a ser visto como o "hôme" que estava sempre com "o Emílio, o crente", como ouvi algumas vezes. No fundo me revelava ao Outro nem tão estranho assim, pois parecia que, se transitava de automóvel com a família pela cidade com freqüência - e todos observavam isso -, algo fazia sentido, um quê de familiar paulatinamente passava a existir em mim aos olhos curiosos dos miguelinos, apesar das diferenças.

Paralelo a isso, o fato de ser "um hôme de Porto Alegre fazendo uma pesquisa" como seu Dorcino me apresentava algumas vezes a seus conhecidos, tinha algumas implicaçóes que estavam carregadas de ambigüidades, ficando evidentes na convivência com as pessoas. Nestes termos eu era: "da capital", "estudado", "da universidade", "de orige" (branco, de olhos verdes, cabelo castanho), "professor", "rico", "moço", "macho" e tudo o que isso representa, obviamente, como forma de poder. Em torno de mim orbitava uma série de representaçôes, de imagens e idéias acerca dos meus "papéis". Havia a "visibilidade" e seus signos da diferença. Corpo estranho transitando no contexto citadino: um certo "exotismo" nos primeiros tempos me fazia ser notado, espiado e comentado na simpática paisagem urbana miguelina.

É verdade que o significado da minha presença junto à família Santos e o que isso representou à população urbana e rural de São Miguel é algo que não tive controle. Afirmo 
isso, no sentido de que possa existir algum nível de status atribuído pela comunidade à família por conviverem comigo, um "professor" de Porto Alegre... Se tal situação existiu, foi independente a minha vontade.

Creio que minha inserção no município foi suficientemente intensa, convivendo com inúmeras pessoas, onde parece ter ficado claro que a "relação familiar" estabelecida com o casal e suas filhas, como também junto a seus parentes, mais do que aquela do "hôme" ou "moço" que veio da cidade grande realizar uma pesquisa na região era de amizade. Para algumas pessoas eu era visto como um sujeito sempre disposto a uma prosa - sobre histórias "dos antigo", sobre "assombros" e "enterro de dinhero-oro" -, com quem quer que fosse, sem, no entanto, significar que proseasse com todo mundo e que náo existissem pessoas com as quais, porventura, não simpatizasse.

\section{Etnografia, amizade e emoção em terras missioneiras}

Minha experiência como etnógrafo em São Miguel das Missôes foi intensa, devido à participação da família Santos, como pessoas dispostas a me auxiliar na aventura pessoal e acadêmica em terras missioneiras. Devo a eles não apenas um rico conjunto de informaçóes que me disponibilizaram, como também um estofo emocional e a oportunidade de experienciar a diferença, permitindo-me lidar com a nova vivência em terras estranhas nas paisagens missioneiras.

As longas conversas com seu Emílio em sua morada eram fundamentais para mim e, geralmente, ocorriam à noite após a sua rotineira labuta no viveiro de mudas que mantém em sua chácara. Os diálogos cumpriam um duplo papel, pois me inseriam no contexto miguelino, mostrando assim a complexidade da cultura missioneira por intermédio de um observador astuto como ele, aliado às conversas que mantinha com sua família como forma de sociabilidade.

Seu Emílio pode ser considerado como o personagem central da etnografia - como Ben Mohammed na pesquisa de Paul Rabinow ${ }^{3}$ no Marrocos. Tornamos-nos, paulatinamente amigos, e acima de tudo companheiros de pesquisa. Daí que sua posição de "informante" sempre esteve vinculada ao fato de apresentar questóes importantes à pesquisa etnográfica, no sentido de esclarecimentos de temas que não compreendia, me ensinando e orientando quanto aos mesmos. Portanto, uma relação dialógica se fez presente todo tempo em que permaneci no local.

Ele e sua família me apresentaram a sua vasta rede social, quando consegui contatar com um número significativo de pessoas em terras miguelinas graças a sua disponibilidade de me conduzirem a locais distantes e me apresentarem como amigo, pois a própria forma de ser missioneira impóe certa reserva ao estrangeiro. O caráter introspectivo do "homem missioneiro" ressaltado por Gilberto Freyre (1973) é um fato a ser considerado, se não determinante nas relações com o Outro - o diferente -, pelo menos aparecendo como um aspecto significativo no processo de aproximação e de interação dialógica.

Há uma necessidade de ser apresentado e de ser "narrado" pelo Outro para o Outro, que quer saber quem é "o moço" e porque está ali querendo conversar com ele. Além disso, existe uma problemática histórica de violência simbólica (Bourdieu, 1998) impetrada por intelectuais da área do patrimônio na região missioneira, pelo menos desde a chegada do SPHAN em terras missioneiras a partir da década de 1930

3. Me apoio nesse ponto da discussão nas reflexôes estabelecidas por Paul Rabinow no seu livro Un Ethnologue au Maroc, 1988, p. 127-133. 
- quando as imagens barrocas dos santos de pau oco, produzidas no período das Reduçóes foram retiradas dos moradores para compor o acervo de estatuas do Museu das Missóes - e que se perpetua de inúmeras formas no universo social missioneiro.

Concordo com Paul Rabinow quando reflete sobre a sua relação com Ben Mohammed e afirma que aos poucos entre eles florescia uma confiança fundada "sobre uma clara apreensão" de suas "diferenças", ao mesmo tempo, que "um respeito mútuo", pois experienciei algo similar na relação com seu Emílio - também com seu Frutuoso e seu Maneco, ou mesmo, com seu Dorcino e dona Alzira, todas elas pessoas cuja relação foi pautada em confiança e respeito mútuo.

Meu anfitrião, Emílio, permitia que estabelecêssemos um tipo de vínculo peculiar dialogando sobre questóes que nos interessavam mutuamente e que, assim como no caso de Rabinow em relação a seu amigo, faziam com que "um outro tipo de comunicação" viesse à tona, pois determinadas "discussōes impossíveis com outras pessoas ocorriam com ele". As experiências dialógicas, por outro lado, com sua esposa, bem como com Mara e seu Frutuoso, aparecem como similares a sua para o contexto da pesquisa etnográfica.

Diferentemente dos demais, meu amigo também tinha outro interesse comum aos meus, dizendo respeito a sua curiosidade em descobrir mais acerca de sua própria cultura e de tirar disso as suas próprias conclusōes. Seu Emílio é, certamente, uma espécie de pesquisador nativo que desempenhou um papel crucial durante a pesquisa, inclusive, direcionando muitas vezes as entrevistas sempre abertas, para os temas de interesse da mesma. Havia também um tipo de sintonia entre nós fazendo com que, ao longo da entrevista, nos comunicássemos pelo olhar, de maneira a externarmos um ao outro que aquele tema que o idoso mencionava durante a conversa remetia a uma boa questão, devendo, portanto, ser melhor explorado.

O fato de seu Emílio ser considerado um amigo jamais significou que o meu papel como pesquisador desaparecesse enquanto tal, como se a relação informante/antropólogo não existisse, diluindo as diferenças entre nós. Ficava claro nesse jogo era a questáo de que não existia uma marcação "dura" de papéis no processo de interação e de encontro intercultural. Eu era o antropólogo em campo, mas acima de tudo, um sujeito emocionalmente inclinado a interagir com as pessoas numa perspectiva igualitária que não representava de forma alguma a eliminação da diferença. E era isso que nos aproximava.

A situação de indivíduo oriundo "da capital" - portanto da metrópole - estudado e detentor de certos conhecimentos me distinguia na população miguelina. Todavia, tais saberes, não eram de grande valia para a vida dura no campo, o que me fazia desconhecedor de certos códigos dominados na região no que se refere ao mundo agrário e às relaçóes sociais a ele vinculadas.

Seu Emílio, desde que nos conhecemos, sabia muito bem disso e lidava com a questão da forma mais solícita possível, no sentido de me auxiliar naquilo que fosse preciso em minha experiência no interior do Estado, visto que era um sujeito tipicamente urbano em meus hábitos e visóes de mundo. Sempre pareceu que para ele e sua esposa eu era um rapaz oriundo da capital realizando uma pesquisa naquela cidade. Portanto, me orientavam frente a determinadas circunstâncias que apareciam como situaçôes novas, considerando-se certa "proteçáo" ao estrangeiro. 


\section{Por uma etnografia das emoçóes ${ }^{4}$ nas fronteiras culturais: experiência ${ }^{5}$ e revelaçáo (visão especular e subjetividade) ${ }^{6}$}

Como dimensionar a riqueza de uma experiência etnográfica? De que forma é possível dar conta da complexidade de um universo de pesquisa, considerando os vários atores sociais que tomam parte do mesmo? Como dar voz a todos - quando passam de setenta as pessoas cotejadas pela pesquisa -, considerando-os como co-participes do processo de construção do conhecimento etnográfico? Qual é a verdadeira medida entre poder e os limites do etnó-

4. Aqui sigo a perspectiva de Vincent Crapanzano (1994) que considera a importância do papel das emoçôes na reflexão de si mesmo, partindo do princípio de que a "categoria emoção" auxilia mediante as suas conotaçôes afetivas numa reflexão crítica ao próprio conjunto de conceitos da antropologia. A questão aponta para as emoções como dimensão reflexiva do self do antropólogo, ao mesmo tempo em que se refere a uma abertura às emoçóes do Outro.

5. Quanto à reflexão sobre a experiência sigo a perspectiva de Kapferer (1986) que se aproxima da de Victor Turner. Ao apontar para o fato de que o sujeito quando vivencia suas experiências acaba por refletir sobre elas, Kapferer tende a compreender o próprio corpo enquanto um espaço reflexivo considerando-se sempre a situaçáo na qual o sujeito se encontra. Para o autor, o ato de experienciar, sendo algo complexo, permite dizer que "eu sou a experiência”. Entretanto, não se trata apenas do próprio ponto de vista do sujeito, pois as outras pessoas têm influência sobre esse fenômeno, deflagrando-se assim a importância do olhar do outro na formação do si mesmo, na medida em que se revela uma construção social singular, configurada na multiplicidade das experiências culturais dos diferentes grupos humanos. De acordo com Kapferer, o sujeito é capaz de compreender a sua açáo, experienciando-a, bem como a experiência do outro através da sua situação no mundo. Por outro lado, a sua experiência se imiscui num conjunto culturalmente constituído de construtos, conceitos e tipificaçóes. O sujeito, portanto, entende a experiência do outro diretamente através da sua e, indiretamente, através da mediação de uma variedade de construtos culturais. Ainda, segundo o autor, tais grafo na construção da narrativa etnográfica, tendo em vista a presentificação dos atores no processo delicado de configuração de sua intriga? É possível traduzir um universo cultural complexo em suas imagens e sentidos, como o caso do missioneiro, sem incorrer em algum nível em reducionismos?

Eis o dilema entre o vivido na intensidade da etnografia enquanto ação, como prática cultural experienciada e a textualização. A etnografia percebida como uma ordem simbólica que aspira traduzir sistemas culturais singulares, busca apreender elementos da cultura do Outro como forma de entendimento do mundo mediante a reflexão científica ${ }^{7}$.

construtos através de sua mediação são vitais na constituição da socialidade e no compartilhamento intersubjetivo da experiência (Kapferer, 1986, p. 190). Jean-Paul Sartre (1995) em sua crítica à psicologia visando uma fenomenologia das emoçóes sinaliza para a importância do conceito de experiência na reflexão sobre a emoçáo. De acordo com Sartre, a psicologia definiria dois tipos de experiências: uma fornecida pela percepção espaçotemporal dos corpos organizados e outra, relacionada ao conhecimento intuitivo de "nós-mesmos" que poderia ser denominada de "experiência reflexiva". Yi-Fu Tuan afirma que por experiência deve-se compreender um "termo que abrange as diferentes maneiras através das quais uma pessoa conhece e constrói a realidade" (Tuan, 1983 , p. 7-9). Segundo este autor, as abstraçôes dependem das experiências.

6. Para as reflexôes que seguem, inspiro-me em Teresa P. do Rio Caldeira (1988; 1989); Stephen Tyler (1991); George Marcus (1994); James Clifford (1998) e Paul Rabinow (1999).

7. "Traduzir não significa ficar no interior do próprio saber nem permanecer no objeto, mas significa estar na diferença, confrontando a linguagem do tradutor com aquela do traduzido. $\mathrm{O}$ imperativo da fidelidade não pode suprimir as diferenças fundamentais que existem entre idiomas. Cada tradução é uma interpretação que sempre implica uma irremediável diferença entre o discurso originário e a sua reprodução (Gadamer, 1965). Esta se origina no hiato entre dois diferentes horizontes, e é caracterizada por uma forma de incomensurabilidade (Kuhn, 1962; Feyerabend, 1975) e entropia (Quine, 1960)" (Malighetti, 1996:89). 
Há, por certo, um questionamento da cultura do antropólogo e uma limitação na própria ação cultural de etnografar aquilo que é o vivido para o nativo, porque o vivido excede a capacidade de traduzir. A experiência escorre entre os dedos. Restam fragmentos de sentidos, flashes fugazes, ainda que poderosos dessa experiência que é preciso recompor - uma ficcionalidade científica - para ser possível engendrar uma hermenêutica capaz de ofertar imagens e sentidos a sua comunidade de linguagem. A etnografia aparece como forma de interpretação da cultura do Outro que segue vivendo e sendo o que é, para que possamos ver-nos como Outros em relação a Eles.

As representaçôes em relação ao Outro são um misto de poder e redenção: de tentativa ideológica de domínio de suas categorias de entendimento para contrapô-las e aproximálas àquelas do antropólogo, bem como de exegese cultural em que o olhar é o de curiosa empatia enquanto experiência com a diferença. Nesse contexto, o antropólogo é símbolo de uma cultura que não consegue se pensar senão olhando-se no espelho do Outro, para que possa conhecer melhor, os próprios nexos que a colocam em movimento.

O antropólogo é o mensageiro do Outro para os seus pares. Enquanto isso permanece o outro único da experiência com o nativo, que detém uma leitura do antropólogo, daquele sujeito que viveu um período junto a ele e que deixou lembranças, mais ou menos obscuras, em sua memória.

A etnografia segue sendo uma tentativa de lidar com a finitude da experiência (e do ser), de aderir aos sentidos da experiência cultural do Outro que lhe escapa, porque não está preso ao universo etnográfico que o antropólogo constrói em sua narrativa, pois segue vivendo - ou mesmo, morrendo como se sucedeu com algumas pessoas desta etnografia. Paradoxalmente, a integra como presença vivida outrora no próprio existir do etnógrafo, na sua memória de interação com esse Outro. A viagem do antropólogo é solitária, mas nem por isso menos gratificante.

Ao antropólogo cabe lidar com a sua capacidade mnemônica de capturar a diferença nas imagens mentais, nos fluxos de sua memória, naquilo que foi o vivido e que está registrado nas linhas de seu diário de campo: um conjunto de elipses e pontos de fuga, de presenças fragmentárias e de totalidades provisórias, de apontamentos e reflexóes acerca de situaçóes, de acontecimentos anotados às pressas na caderneta ou registrados na solidão e, aí, a imagem idiossincrática de Malinowski é paradigmática.

O antropólogo experimenta a possibilidade desesperada de registrar a totalidade, mas deve se regozijar com o fragmento pleno de sua experiência. São as reminiscências do campo - nas imagens mentais e fotográficas, bem como nos apontamentos do diário - que bus$\mathrm{ca}$, como a fonte da qual extravasam e fluem os mananciais, os elementos que irão compor a sua narrativa etnográfica em que realizará a colagem e a experimentação que é a produção textual.

$\mathrm{O}$ ato de etnografar e textualizar é emocional ou, simplesmente não o é. É desse plano da consciência criadora e dessa força imaginária que a razão científica emerge como mais uma forma de compreensão do mundo. Porque o "objeto" na medida em que é "sujeito" (Matta, 1993) complexifica o próprio intento científico de apreendê-lo como forma sutil de experiência humana no mundo.

Portanto, é a própria pessoa do antropólogo que deve ser arrebatada pelo enlace, não significando com isso, que a fusão de horizontes represente aceitação tácita do Outro em tudo o que ele representa. A diferença é vivida no afeto e no asco, na alegria e na aflição, mas acima de tudo, na beleza existente na própria capacidade 
do etnógrafo de narrá-lo como sujeito consciente no mundo a que pertence, sem deixar de se colocar nesse processo.

Uma das questôes fundamentais na discussão que me propus realizar na tese implica em como transpor, no sentido de textualizar, os aspectos subjetivos relacionados à minha imersão no universo missioneiro riograndense num período de dez meses - uma experiência etnográfica vivida enquanto encontro intercultural intenso -, sem cair num subjetivismo exacerbado. Resguardo um sentimento de estupefação - de amaravilhamento e espanto -, ante uma experiência singular, cuja magnitude me encanta e arrebata pelas complexidades que traz consigo.

Há uma premissa muito básica, porque óbvia, na minha experiência enquanto antropólogo: aprendi muito com as pessoas as quais conversei, mas acima de tudo, se exercitei a capacidade de escutá-las, permitindo com isso construir meu "documento", como diria seu Emílio, por outro lado, experienciei um nível de interação humana sutil que é comovedora em seus desígnios e que re-situa meu lugar no mundo como sujeito produtor de conhecimento.

As interpretaçôes que compóem a etnografia sobre a cultura missioneira, apresentam certa proximidade com um plano místico, referindose a determinadas situaçóes e fenômenos cuja explicação são complexas para compreendê-los, usando apenas a razão que se propóe científica. Aqui não há nenhum demérito a essa forma de pensar os fenômenos do mundo. Pelo contrário, busquei a partir de meu intento acadêmico, construir uma etnografia em que as dimensóes da vida social (as quais vibram num nível menos denso, subliminar) cruzassem a experiência do antropólogo em seu ofício e subjetividade.

Se, porventura, há algum tom teleológico aí, não é aquele que busca a verdade final, mas sim uma abertura ao fluxo de energias que guiam o social na sua experiência com imagens e sentimentos; na interação das forças emocionais
(Rosaldo, 1991) que envolvem paradoxos e sintonias nas formas de manifestação das consciências presentes no mundo8.

Náo creio que ao desembocar em questóes subjetivas no que tange às reflexôes que estabeleço quanto ao elo construído por mim com algumas pessoas que convivi ao longo desse período, acabe por "fragilizar" minhas argumentaçóes como pesquisador produzindo conhecimento acadêmico, pois esses tantos "Outros" cuja proximidade me causou imensa satisfação, possibilitaram que dessa relação intersubjetiva emergissem as minhas próprias questóes enquanto "sujeito descentrado" pela imersão etnográfica. De certa maneira, ao abrir-me às possibilidades e vicissitudes de experienciar formas singulares de interação social noutras paisagens culturais, acabei me impregnando de tal forma dessa força emocional, que ela afeta diretamente a minha própria situação de narrador em etnografia.

8. Tanto Renato Rosaldo (1991) quanto Vincent Crapanzano (1994), ao destacarem a importância das emoçóes na pesquisa etnográfica apontam para o caráter "transformador do mundo" (Sartre, 1999) que a emoçáo engendra. Ela apresenta um papel significativo no próprio exercício etnográfico. A emoção, sendo considerada uma estrutura e forma da consciência do sujeito é também consciência do mundo. Daí que a perspectiva de Lucien Lévy-Bruhl, quando "torna o sentimento ou a afetividade uma das dimensóes inerentes ao processo de conhecimento, ainda que menos determinante se comparado à razão" (Cardoso de Oliveira, 1991, p. 14) é importantíssima para a compreensão dos fenômenos humanos estudados em antropologia. $\mathrm{Na}$ verdade, tais questóes sugerem uma "razão sensível" capaz de engendrar um "saber que saiba, por mais paradoxal que isso possa parecer, estabelecer a topografia da incerteza e do imprevisível, da desordem e da efervescência, do trágico e do não-racional. Coisas incontroláveis, imprevisíveis, mas não menos humanas. Coisas que, em graus diversos, atravessam as histórias individuais e coletivas" (Maffesoli, 1998, p. 13). 


\section{Consideraçóes finais}

A narrativa etnográfica que me propus se refere a uma espécie de mergulho no regime de imagens ${ }^{9}$ presentes na cultura missioneira, significando que as mesmas nutrem o mundo simbólico dessas comunidades. Daí a importância dos sentidos, das categorias e emoçôes relacionadas ao um universo fantástico e complexo impregnado na memória coletiva dos habitantes das cidades da regiáo para a compreensão, fragmentária, tênue e limitada, por certo, das sutilezas do mundo sensível do homem missioneiro.

Conforme Paul Ricoeur é necessário considerar "o caráter temporal da experiência humana", onde "o tempo torna-se tempo humano na medida em que está vinculado de modo narrativo; em compensação, a narrativa é significativa na medida em que esboça os traços da experiência temporal" (1994, p. 15). Portanto, narrar implica no exercício fantástico da memória vinculado a "organização inteligível da narrativa”. A afirmaçáo anterior é válida tanto para o narrador de causos como para o antropólogo, na construção de sua narrativa etnográfica.

9. Aqui me guio pelas reflexóes durandianas: "A imanência da nossa fantasia suscita como que uma imaginação dialogada da alma solitária: a anima ergue-se entáo face ao animus e a consciência sonhadora torna-se uma dupla, um abraço de imagens, diálogo em perfeita concordância. Esta abertura, esta amplificação interna da consciência sonhadora, proíbe-lhe tanto a alienaçáo como o solipsismo. A dialéctica interna à fantasia dialogada reequilibra incessantemente a sua humanidade e, por uma espécie de pilotagem automática, remete incessantemente o conhecimento à problemática da condição humana. A anima surge assim como o anjo dos limites que protege a consciência nos desvios para o angelismo da objectividade, para a alienação desumanizante. $\mathrm{O}$ anjo é, de certo modo, transcendental: a consciência que se decalca na objetividade perde todo o seu poder de transcendência e, ao querer fazer de anjo, torna-se Lúcifer” (Durand, 1993, p. 68).
Para Paul Ricoeur agir é sempre agir com outros, implicando a interação. Nesse sentido, o ato de narrar é ele próprio um ato de criaçáo poética, de uma "inteligência poética" - apresentando um caráter dialógico -, onde "a ação pode ser narrada" na medida em que está relacionada a episódios que, nos termos de Victor Turner (1974) se referem a "dramas sociais" que trazem subjacentes determinados conflitos sociais, apresentando relaçóes com uma intriga a ser engendrada na configuração da narrativa.

A intriga surge como uma capacidade expressiva do si-mesmo configurar - de considerar junto - as açóes e incidentes sociais, de maneira a dar forma a uma totalidade temporal que, mediante o ato poético, permite que o narrador seja capaz de conformar um construto narrativo - mediante a "tessitura da intriga", conforme Ricoeur. A intriga está ligada a um encadeamento, a uma lógica, envolvendo uma ordenação ou sucessão que se refere ao agenciamento dos fatos que configuram a narrativa (Ricoeur, 1994, p. 63-7).

Assim, a narrativa é um desfiar de histórias que tem consigo um vaivém da memória, trazendo à tona imagens e episódios vividos num tempo outro que aparecem à luz do presente (Benjamin, 1980). O narrador revive a experiência vivida (Bosi, 1994).

Parece-me plausível vislumbrar os sincronismos presentes em eventos que conjugam forças e imagens, sempre tensionadas pelas diacronias oriundas desse processo de convergência de imagens e energias emocionais, vinculados à historicidade e engendrando mudanças no corpo social, acabando assim, por acomodá-lo àquilo que é o seu devir no processo dinâmico de interaçáo com o cosmos.

As maneiras de lidar com tempos que se cruzam - mas que também se mesclam, sedimentam e desdobram - é algo peculiar às formas culturais que se instauram num meio, apresentando-se profundamente interconectados. 
No que tange a esta pesquisa, o interesse recaiu sobre os vínculos entre elementos típicos das paisagens missioneiras do noroeste do Estado, com uma fantástica que lhe é inerente, como expressão do imaginário dos grupos humanos naquela região.

As relaçóes complexas entre esses níveis do simbólico puderam ser compreendidas, pelo menos parcialmente, mediante uma maior atenção às experiências vividas pelos missioneiros - e para o caso da pesquisa, principalmente, pelos miguelinos - enquanto componentes fundamentais na dinâmica dessas paisagens, bem como no ato criativo de tecer elaboradas narrativas, mediante as labutas das memórias individuais dos sujeitos. Elas mesmas, tributárias de uma memória coletiva que arrebata o etnógrafo em experiência de campo.

The poetic of the missionary daily: ethnography and reflection on themselves. Sharing images and emotions with the 'causos' tellers in the Gaúchas Missons.

abstract The intention of this work is placing the reader in the ethnographic panorama in which happened the fieldwork, trying to present some relevant subjects for the ethnographic exercise noticed as an intersubjective encounter. In these terms, the emotions involved in the poetic of the daily missionary snatches the ethnographer, at the same time that they appear for the disconstruction of certain world visions, implicating in a theoretical and intellectual resize, starting from an intersubjective dialogic experience given in the conviviality with the Other.

keywords Emotions. Ethnography. Informer.

\section{Referências bibliográficas}

BENJAMIN, Walter. O Narrador. In: Benjamin, Adorno, Horkheimer, Habermas. São Paulo: Abril Cultural, 1980, p. 53-85. (Coleção Os pensadores).
BERREMAN, Gerald D. Etnografia e controle de impressões em uma aldeia do Himalaia. In: ZALUAR, A. (Org.). Desvendando Máscaras Sociais. Rio de Janeiro: Francisco Alves, 1980, p. 123-174.

BOSI, Ecléa. Memória e sociedade: lembranças de velhos. São Paulo: Companhia das Letras, 1994. 488 p.

BOURDIEU, Pierre. O poder simbólico. Rio de Janeiro: Bertrand Brasil, 1998. 316 p.

CALDEIRA, Teresa P. do R. A presença do autor e pósmodernidade na Antropologia. Novos Estudos CEBRAP, São Paulo, n. 21, p.133-157, 1988.

Antropologia e Poder: uma resenha de etnografias americanas recentes. $B I B$, Rio de Janeiro, n. 27, p. 3-50, 1989.

CARDOSO DE OLIVEIRA, Roberto. A categoria de (des) ordem e a pós-modernidade na antropologia. Anuário Antropológico, Rio de Janeiro: Tempo Brasileiro/UnB, p. 57-73, 1986.

Razão e Afetividade: o pensamento de Lucien Lé$v y$-Brubl. Campinas: UNICAMP, 1991. 180 p.

CATANI, M. L. "Histoire de vie sociale de Tante Suzanne est un échange oral ritualisé”. In: DELHEZ-SARLET, C. ; CATANI, M. Individualisme et autobiographie en Occident. Bruxelles: Éditions de l'Université de Bruxelles, 1983, p. 63-72.

CERTEAU, Michel de. A invenção do cotidiano: artes de fazer. Rio de Janeiro: Vozes. 1994, v. 1.352 p.

CLIFFORD, James. A experiência etnográfica: antropologia e literatura no século XX. Rio de Janeiro: UFRJ, $1998.320 \mathrm{p}$.

CRAPANZANO, Vincent. Diálogo. Anuário Antropológico. Rio de Janeiro: Tempo Brasileiro/UnB, v. 8, 1991, p. 59-80.

Réflexions sur une anthropologie des émotions. Terrain, 1994, p. 109-117.

DURAND, Gilbert. As estruturas antropológicas do imaginário. Lisboa: Presença. 1989. 328 p.

O imaginário: ensaio acerca das ciências e da fllosofia da imagem. Rio de Janeiro: DIFEL, 1998. 126 p.

DURKHEIM, Émile; MAUSS, Marcel. De ciertas formas primitivas de clasificación: contribuición al estudio de las representaciones colectivas. Instituición y culto. Representaciones colectivas y diversidad de civilizacionnes. Barcelona: Barral Eds., 1971, p. 13-73.

ECKERT, Cornelia; ROCHA, Ana Luiza Carvalho da. A interioridade da experiência temporal do antropólogo como condição da produção etnográfica. Revista de Antropologia, São Paulo, n. 2, p. 107-135, 1998. 
ELIAS, Norbert. A sociedade dos indivíduos. Rio de Janeiro: Jorge Zahar Editor, 1994. 204 p.

EVANS-PRITCHARD, E. Os nuer. Sáo Paulo: Perspectiva, $1993.276 \mathrm{p}$

FISCHER, Michael. M. J. Da antropologia interpretativa à antropologia crítica. Anuário Antropológico, Rio de Janeiro: Tempo Brasileiro/UnB, n. 83, p. 55-72, 1985.

FOOTE-WHYTE, William. Treinando a observação participante. In: ZALUAR, A. (Org.). Desvendando máscaras sociais. Rio de Janeiro: Francisco Alves, 1980, p.77-8.

FREYRE, Gilberto. Problemas brasileiros de antropologia. Rio de Janeiro: Livraria José Olympio/MEC, 1973. 362 p.

HALL, Edward. A dimensão oculta. Rio de Janeiro: Francisco Alves, 1977. 266 p.

KAPFERER, B. Performance and the structuring of meaning and experience. In: TURNER, V.; BRUNER, E (Ed.). Antropology of experience.Chicago: University of Illinois Press, 1986, p. 188-203.

LAGROU, Elsje. M. Hermenêutica e etnografia: uma reflexão sobre o uso da metáfora da textualidade para "ler" e "inscrever" culturas ágrafas. Revista de Antropologia, São Paulo: USP, v. 37, p. 35-55, 1994.

MAFFESOLI, Michel. Elogio da razão sensivel. Petrópolis: Vozes, 1998. $207 \mathrm{p}$.

MALIGHETTI, R. O trabalho etnográfico: circularidade, hermenêutica e dialogismo. Revista Politicas Públicas, São Luís, v. 2, p. 45-86, 1996.

MALINOWSKI, Bronislaw. Um diário no sentido estrito do termo. Rio de Janeiro: Record. 1997. 336 p.

MARCUS, George. O que vem (logo) depois do "pós": o caso da etnografia. Revista de Antropologia, São Paulo: USP, v. 37, p. 7-34, 1994.

PASQUARELLI JR, Vital. Diálogo e pensamento por imagem: etnografia e iniciação em las enseńanzas de Don Juan, de Carlos Castañeda. Revista Brasileira de Ciências Sociais, n. 29, p. 103-126, 1995.

RABINOW, Paul. Un ethnologue au Maroc: refléxions sur une enquête de terrain. Paris: Hachette, 1988, p. 127-133.
Antropologia da razão. Rio de Janeiro: Relume Dumará, 1999. 203 p.

RICOEUR, Paul. Tempo e narrativa. São Paulo: Papirus, 1994, v. 1.324 p.

Teoría de la interpretación, discurso y excedente de sentido. Siglo Vientiuno Editores, 1995. 112 p.

ROSALDO, Renato. Cultura y verdad: nueva propuesta de análisis social. México: Grijalbo,1991. 253 p.

SARTRE, Jean-Paul. Esquisse d'une théorie des émotions. Paris: Hermann, 1995. 123 p.

SILVEIRA, Flávio L. A. da. As paisagens fantásticas e o barroquismo das imagens: estudo da memória coletiva dos contadores de causos da região missioneira do Rio Grande do Sul. Porto Alegre, 2004. 764 f. Tese (Doutorado em Antropologia Social) - Universidade Federal do Rio Grande do Sul.

SIMMEL, Georg. Sociología: estudios sobre las formas de socialización. Revista de Ocidente, Madrid: Alianza, 1977, 2.v. (Alianza Universidad; v. 479-480).

Sociologia. In: Moraes Filho, Evaristo de (Org.). São Paulo: Ática, 1983. 192 p.

TEDLOCK, Dennis. A tradição analógica e o surgimento de uma antropologia dialógica. Anuário Antropológico, Rio de Janeiro: Tempo Brasileiro/UnB, v. 85, p. 183-202, 1986.

TUAN, Yi-Fu. Espaço \& lugar: a perspectiva da experiência. São Paulo: Difel, 1983. 252 p.

TURNER, Victor. Dramas, Fields and Metaphors: Symbolic Action in Human Society. Ithaca and London: Cornell University Press, 1974. 309 p.

TYLER, Stephen. La etnografia posmoderna: de documento de lo oculto a documento oculto. In: GEERTZ, C.; CLIFFORD, J. et al. El surgimiento de la antropologia posmoderna. México: Gedisa Editorial, 1991, p. 297-314.

VELHO, Gilberto. Projeto e metamorfose: antropologia das sociedades complexas. Rio de Janeiro: Jorge Zahar Editor, 1994.137 p.

\title{
autor Flávio Leonel Abreu da Silveira
}

Professor do Departamento de Antropologia/UFPA

Doutor em Antropologia Social/UFRGS

\author{
Recebido em 05/02/2006 \\ Aceito para publicação em 16/03/2007
}

